\title{
Tracing Mercury Pollution along the Norwegian Coast via Elemental, Speciation, and Isotopic Analysis of Liver and Muscle Tissue of Deep-Water Marine Fish (Brosme brosme)
}

\author{
Ana Rua-Ibarz, ${ }^{\dagger, \S}$ Eduardo Bolea-Fernandez, ${ }^{\dagger, \S}$ Amund Maage, ${ }^{\ddagger}, \#$ Sylvia Frantzen, ${ }^{\ddagger}$ Monica Sanden,
} and Frank Vanhaecke*,†이
${ }^{\dagger}$ Ghent University, Department of Chemistry, Atomic \& Mass Spectrometry Research Unit, Campus Sterre, Krijgslaan 281-S12, 9000 Ghent, Belgium

${ }^{\ddagger}$ Institute of Marine Research, Postboks 1870 Nordnes, 5817 Bergen, Norway

Supporting Information

\begin{abstract}
Liver and muscle tissue of tusks (Brosme brosme) have been analyzed for their $\mathrm{THg}$ and $\mathrm{MeHg}$ concentrations and $\mathrm{Hg}$ isotopic signatures for tracing $\mathrm{Hg}$ pollution along the Norwegian coast. Clear differences between tissue types and locations were established. At five of the eight locations, the $\mathrm{Hg}$ concentration in muscle exceeded the maximum allowable level of $0.5 \mathrm{mg} \mathrm{kg}^{-1}$ wet weight. $\delta^{202} \mathrm{Hg}$ values in both tissue types indicated that $\mathrm{Hg}$ speciation affects the bulk $\mathrm{Hg}$ isotopic signature. Tusk liver seems to be more sensitive to immediate changes and to anthropogenic inorganic $\mathrm{Hg}$, while the muscle rather reflects the $\mathrm{Hg}$ accumulated over a longer period of exposure. The $\delta^{202} \mathrm{Hg}$ values of liver and muscle also enabled different sources of $\mathrm{Hg}$ and exposure

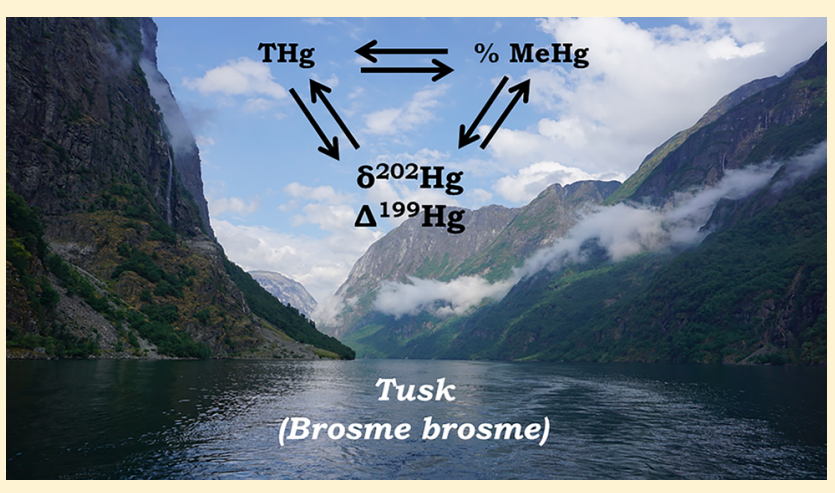
pathways to be distinguished. $\delta^{202} \mathrm{Hg}_{\text {muscle }}-\delta^{202} \mathrm{Hg}_{\text {liver }}$ showed a clear correlation with the \% MeHg in tusk liver for the coastal waters, but not for the fjords. The absence of significant differences in $\Delta^{199} \mathrm{Hg}$ values between both tissues of tusk from the same location suggests that in vivo metabolic processes are the underlying reason for the differences in $\mathrm{Hg}$ speciation and in $\delta^{202} \mathrm{Hg}$ values. This work highlights the importance of selecting different tissues of marine fish in future $\mathrm{Hg}$ monitoring programs.
\end{abstract}

\section{INTRODUCTION}

Mercury $(\mathrm{Hg})$ is one of the most important global pollutants. It occurs in the environment as a result of natural and anthropogenic sources and both wildlife and humans are exposed to the harmful effects of this highly toxic heavy metal and its compounds. Anthropogenic $\mathrm{Hg}$ emissions resulting from a variety of processes, such as coal combustion, metal refining and manufacturing, cement production and waste incineration, are the main contributors to the worldwide increasing $\mathrm{Hg}$ levels. ${ }^{1} \mathrm{Hg}$ is globally distributed through the atmosphere, atmospheric deposition being the largest source of $\mathrm{Hg}$ to the oceans. In aquatic ecosystems, inorganic $\mathrm{Hg}$ can be converted into methylmercury $(\mathrm{MeHg})$, the most toxic $\mathrm{Hg}$ species. $\mathrm{MeHg}$ can be bioaccumulated and biomagnified across food chains, ${ }^{2}$ making seafood consumption the prime source of human $\mathrm{Hg}$ intake. Norway is the world's second largest exporter of seafood and the related industry is one of the most important pillars of the country's economy. ${ }^{3}$ Given its toxicity, there is increasing attention for $\mathrm{Hg}$ contamination in seafood, an issue requiring proper attention from the health and food safety authorities.

Several aquatic/marine species, in different trophic positions, have been used over the years for tracing $\mathrm{Hg}$ pollution and for improving the understanding of the different pathways of $\mathrm{Hg}$ across aquatic/marine food chains. ${ }^{4}$ A group of special interest comprises common species that do not migrate over large distances. Tusk (Brosme brosme) is such a species. It is a benthic gadoid fish that is distributed widely in Norwegian waters, both in fjords, along the coast and in open ocean areas. Tusk is one of the species of commercial importance for Norway, with catching volumes exceeding $10000 \mathrm{t}$ per year. ${ }^{5,6}$ It is a popular fish for the restaurant market, with its fine taste and texture. ${ }^{7}$ It has been reported that tusk tends to accumulate higher $\mathrm{Hg}$ levels than other fish species living in the same area, e.g., cod. ${ }^{7,8}$ As a result, tusk may be considered as a key species for present and future $\mathrm{Hg}$ monitoring programs. ${ }^{9}$ In addition to monitoring selected marine species, the study of different tissues from the same species might provide further insight aiming at identifying $\mathrm{Hg}$ sources and at unraveling exposure pathways.

Received: August 22, 2018

Revised: November 4, 2018

Accepted: January 17, 2019

Published: January 17, 2019 


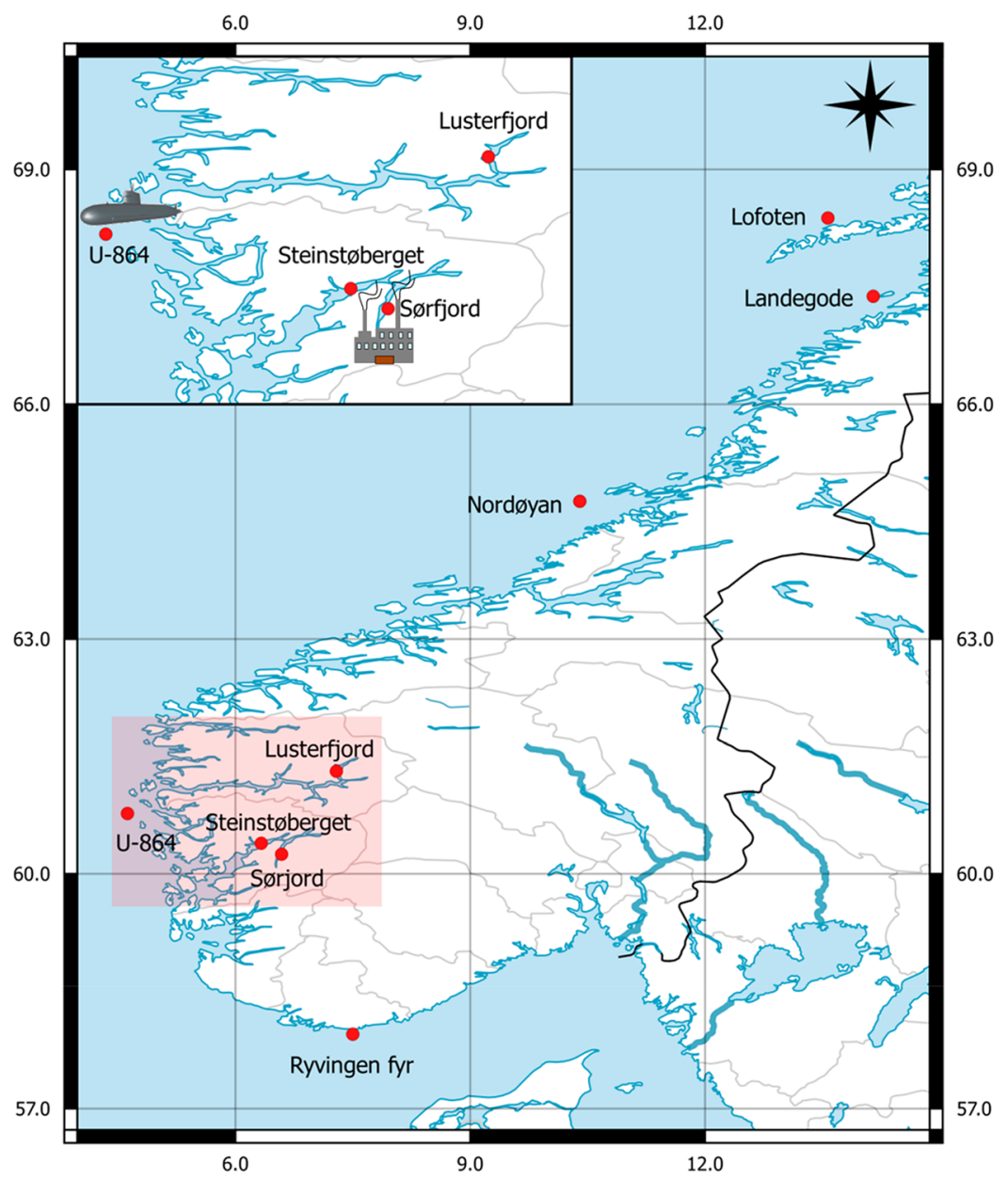

Figure 1. Map of Western Norway showing the sampling locations where the tusks (Brosme brosme) were collected. Fjords: Sørfjord, Steinstøberget, and Lusterfjord. Coastal locations: Ryvingen fyr, U-864, Nordøyan, Landegode, and Lofoten.

Next to elemental and speciation analysis, also $\mathrm{Hg}$ isotopic analysis can contribute to an improved understanding of the complex biogeochemical $\mathrm{Hg}$ cycle. ${ }^{10}$ The isotopic composition of $\mathrm{Hg}$ varies between different sources, and different physical and/or (bio)chemical processes are accompanied by $\mathrm{Hg}$ isotope fractionation. ${ }^{11}$ Mass-dependent fractionation (MDF) was shown to accompany various environmentally relevant processes, such as sorption, ${ }^{12,13}$ equilibrium evaporation, ${ }^{14,15}$ microbial methylation and demethylation, ${ }^{16,17}$ microbial reduction, ${ }^{18}$ and photochemical reduction. ${ }^{19-21}$ It has also been demonstrated that - at least in some species-different in vivo metabolic processes, such as $\mathrm{MeHg}$ demethylation, induce $\mathrm{Hg}$ isotope fractionation. While for mammals, the occurrence of in vivo demethylation is widely accepted, ${ }^{22,23}$ its occurrence in fish is a matter of more controversy, ${ }^{24}$ but several recent papers do claim its existence. ${ }^{25-29}$ As a result, a more profound understanding of the different transformations that $\mathrm{Hg}$ undergoes in nature is mandatory for tracing the origin of $\mathrm{Hg}$ pollution in marine ecosystems by means of $\mathrm{Hg}$ isotopic analysis. In addition to MDF, the isotopic composition of $\mathrm{Hg}$ can also be affected by mass-independent fractionation (MIF), ${ }^{30}$ exhibited primarily by the odd-numbered $\mathrm{Hg}$ isotopes $\left({ }^{199} \mathrm{Hg}\right.$ and $\left.{ }^{201} \mathrm{Hg}\right)$. MIF has been explained by the nuclear volume effect (NVE) and the magnetic isotope effect (MIE). ${ }^{31-34}$ The photoreduction of $\mathrm{Hg}(\mathrm{II})$ and the photodegradation of $\mathrm{MeHg}$ are considered as the main processes yielding "odd-MIF". ${ }^{19}$ As both MDF and MIF of $\mathrm{Hg}$ isotopes occur in nature, $\mathrm{Hg}$ isotopic analysis provides a "multidimensional" tracer and a powerful tool for enhancing our understanding of the biogeochemical $\mathrm{Hg}$ cycle.

In this work, the possibility of using tusk for tracing $\mathrm{Hg}$ pollution along the Norwegian coast has been assessed by means of the determination, speciation and isotopic analysis of $\mathrm{Hg}$ in its liver and muscle tissue. The results obtained have also been used to evaluate which organ/tissue is the best suited for monitoring $\mathrm{Hg}$ exposure.

\section{MATERIALS AND METHODS}

Sample Collection and Sample Preparation. A total of 137 tusk fish (Brosme brosme) were caught at eight different locations along the Norwegian coast (see Figure 1 and Table S1 of the Supporting Information (SI) for further information on the sampling zones). Three of the locations are located in fjords: Sørfjord $(N=8)$, Steinstøberget $(N=25)$, and Lusterfjord $(N=14)$. The remaining five locations are spread along the Norwegian coast (south to north): Ryvingen fyr ( $N$ $=25)$, U-864 $(N=8)$, Nordøyan $(N=25)$, Landegode $(N=$ $25)$, and Lofoten $(N=7)$. "U-864" refers to a location where a WWII submarine wreck carrying 67 tons of metallic $\mathrm{Hg}$ has contaminated the local sediment. ${ }^{35}$

From each fish, liver and muscle tissues were manually separated and homogenized (thus resulting in 274 samples). For the Sørfjord and U-864 locations, the tissues of the individual fish (i.e., 32 tissue samples) were measured 
separately (both for elemental and isotopic analysis). For the other 6 locations, samples of liver and muscle of individual fish from each location were pooled and homogenized. After processing, all samples were stored frozen $\left(<-20^{\circ} \mathrm{C}\right)$ until analysis.

Prior to elemental and isotopic analysis, $0.5-1.2 \mathrm{~g}$ of sample or certified reference material (CRM) were acid-digested with a 3:1 mixture of $7 \mathrm{M} \mathrm{HNO}_{3}$ and $9.8 \mathrm{M} \mathrm{H}_{2} \mathrm{O}_{2}$ in closed microwave vessels using a Milestone (Italy) Ethos One HighPerformance Microwave Digestion System (the microwave program was selected following the instructions of the manufacturer and is given in Table S2). The resulting digests were diluted and subjected to ICP-MS analysis (see SI).

In addition, a sediment sample from the vicinity of the Odda $\mathrm{Zn}$ smelter was collected to assess a possible link with the occurrence of $\mathrm{Hg}$ in fish from the Sørfjord location. Approximately $0.3 \mathrm{~g}$ of this sediment sample (two digestion replicates) and of a CRM were also acid-digested (using the same microwave program-Table S2) with a 3:1:1 mixture of $14 \mathrm{M} \mathrm{HNO}_{3}, 9.8 \mathrm{M} \mathrm{H}_{2} \mathrm{O}_{2}$, and $28 \mathrm{M} \mathrm{HF}$, and subsequently diluted prior to ICP-MS analysis.

Reagents and Standards. Pro-analysis $14 \mathrm{M} \mathrm{HNO}_{3}$ and $12 \mathrm{M} \mathrm{HCl}$ (ChemLab, Belgium), further purified by subboiling distillation in PFA equipment, 9.8 $\mathrm{M} \mathrm{H}_{2} \mathrm{O}_{2}$ (Fluka, Belgium), ultrapure $28 \mathrm{M}$ HF (Fisher Chemicals, Great Britain), and high-purity water obtained from a Milli-Q Element water purification system (Millipore, France) were used for sample digestion and subsequent dilution. For $\mathrm{Hg}$ isotopic analysis, pro-analysis $\mathrm{SnCl}_{2} \cdot 2 \mathrm{H}_{2} \mathrm{O}$ (Sigma-Aldrich, U.K.) was used for $\mathrm{Hg}$ introduction via the reduction of $\mathrm{Hg}^{2+}$ into elemental $\mathrm{Hg}$.

Appropriate dilutions of $1000 \mathrm{mg} \mathrm{L}^{-1}$ stock solutions of As, $\mathrm{Cd}, \mathrm{Cr}, \mathrm{Cu}, \mathrm{Hg}$, In, $\mathrm{Ni}, \mathrm{Pb}, \mathrm{Rh}, \mathrm{Se}$, and $\mathrm{Zn}$ (Inorganic Ventures, The Netherlands) were used as calibration standards for elemental analysis. For isotopic analysis, the $\mathrm{Hg}$ and $\mathrm{Tl}$ isotopic reference materials (NIST SRM 3133 and NIST SRM 997) were used for mass bias correction. An in-house standard solution with well-characterized $\mathrm{Hg}$ isotopic composition

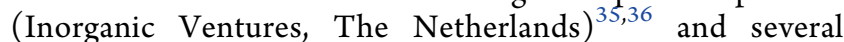
CRMs with a matrix composition similar to that of the samples of interest were used for QA/QC.

Elemental and Isotopic Analysis. A ThermoScientific (Germany) Element XR single-collector sector-field ICP-MS instrument (SF-ICP-MS) was used for elemental analysis; additional information is provided in the SI and in Table S3. For THg quantification QA/QC (method detection limit of 1 $\mu \mathrm{g} \mathrm{kg}^{-1}$ ), different CRMs (BCR CRM 464 tuna fish, NRCCNRC DORM-4 fish protein, TORT-3 lobster hepatopancreas and NIST SRM 2704 Buffalo river sediment) were analyzed for their $\mathrm{Hg}$ content (average recovery of 97\%-Table S4).

$\mathrm{MeHg}$ speciation was performed via isotope dilution gas chromatography ICP-MS (GC-ICP-IDMS) using an Agilent (U.S.A.) $6890 \mathrm{~N}$ gas chromatograph coupled to an Agilent Technologies (Japan) 7500a ICP-MS instrument. The extraction procedure and the details on the GC-ICP-MS method are described elsewhere. ${ }^{37}$ For QA/QC, various CRMs-NRC-CNRC TORT-2 lobster hepatopancreas, DORM-3 dogfish muscle, DOLT-4 dogfish liver, and ERM CE464 tuna muscle-were used. The results were found to be in good agreement with the corresponding certified values $(z$ scores $<|1.5|$ ).

The results obtained upon elemental analysis are expressed as their average \pm standard deviation in the case of the pooled samples. For the Sørfjord and U-864 locations (for which individual fish were measured instead of pooled samples), however, median, minimum and maximum concentrations are reported. All concentrations were expressed on an "as-is" basis or as "wet" values (per unit of wet tissue weight), as also the maximum allowable concentration is expressed on a wet weight basis.

A ThermoScientific (Germany) Neptune multicollector ICP-MS (MC-ICP-MS) instrument with an HGX-200 cold vapor and hydride generation unit for sample introduction (Teledyne Cetac Technologies, U.S.A.) was used for $\mathrm{Hg}$ isotopic analysis (this setup is described in detail elsewhere, ${ }^{36}$ while the instrument settings are provided in Table S5).

Instrumental mass discrimination was corrected for by using the combination of the "Baxter approach"-using Tl (NIST SRM 997) as an internal standard-and external correction in a sample-standard bracketing (SSB) approach using the $\mathrm{Hg}$ isotopic reference material NIST SRM 3133. ${ }^{36,38}$ A description of the CVG-MC-ICP-MS measurement protocol, including $\mathrm{QA} / \mathrm{QC}$, is provided in the SI and in Table S6. ${ }^{35,36}$

Mass-dependent fractionation (MDF) and mass-independent fractionation (MIF) are reported in delta $\left(\delta^{\mathrm{xx}} \mathrm{Hg} \% \mathrm{o}\right)$ and capital delta $\left(\Delta^{\mathrm{xxx}} \mathrm{Hg} \% \mathrm{o}\right)$ notation, respectively (the corresponding equations are given in the SI).

\section{RESULTS AND DISCUSSION}

Mercury Distribution between Liver and Muscle Tissue of Tusk. Concentrations of $\mathrm{THg}$ and $\mathrm{MeHg}$ in liver and muscle tissue of tusks collected along the Norwegian coast are shown in Table S7 and Figure S1. In addition, also those of other environmentally relevant metals-As, $\mathrm{Cd}, \mathrm{Cr}, \mathrm{Cu}, \mathrm{Pb}$, $\mathrm{Ni}$, Se, and $\mathrm{Zn}$ - were determined to evaluate possible links with the occurrence of $\mathrm{Hg}$ in fish tissues. These possible links are indicated along this manuscript, while the overall results are described in the SI and are shown in Table S7 and Figure S2.

Total $\mathrm{Hg}(\mathrm{THg})$ concentrations ranged from 0.11 (Lofoten) to 27 (Sørfjord) $\mathrm{mg} \mathrm{kg}^{-1}$ in liver tissue and from 0.20 (Lofoten) to 2.6 (Sørfjord) $\mathrm{mg} \mathrm{kg}^{-1}$ in muscle tissue, while $\mathrm{MeHg}$ concentrations ranged from 0.050 (Lofoten) to 3.5 (Sørfjord) $\mathrm{mg} \mathrm{kg}^{-1}$ in liver tissue and from 0.18 (Lofoten) to 1.6 (Sørfjord) $\mathrm{mg} \mathrm{kg}^{-1}$ in muscle tissue. $\mathrm{MeHg}$ and $\mathrm{THg}$ concentrations correlated for both liver (Figure S3A) and muscle (Figure S3B) tissues (Spearman's correlation, $r=0.976$ and $0.970, p=0.000$ for liver and muscle, respectively). In addition, a strong positive correlation was found between $\mathrm{THg}_{\text {liver }}$ and $\mathrm{THg}_{\text {muscle }}$ (Figure $\mathrm{S} 3 \mathrm{C}$ ) and $\mathrm{MeHg}_{\text {liver }}$ and $\mathrm{MeHg}_{\text {muscle }}$ (Figure S3D), although a clear deviation from the general behavior is observed for the Sørfjord location, i.e., the most polluted area, for which liver concentrations were particularly high compared to the muscle concentrations (Spearman's correlation excluding the Sørfjord data points, $r$ $=0.964, p=0.000$, and $r=0.955, p=0.001$, for THg and $\mathrm{MeHg}$, respectively).

Overall, liver and muscle of tusks collected in the fjords show higher $\mathrm{THg}$ concentrations than those from coastal locations. This observation was also found for the majority of the other environmentally relevant metals, and it can most likely be attributed to local anthropogenic sources and/or to the poorer water circulation in fjords compared to open ocean areas. Also, the specific morphology of the fjords gives rise to higher accumulation of pollutants, potentially trapped at great depths and for longer periods within the fjord. ${ }^{39}$ 
$\mathrm{THg}$ concentrations were also found to be significantly higher in liver than in the corresponding muscle tissue for tusk from the three fjord locations $\left(\mathrm{THg}_{\text {liver }} / \mathrm{THg}_{\text {muscle }}\right.$ ratio ranging from 1.8 to 4.3 ), while for tusk from the coastal locations, the $\mathrm{THg}$ concentrations in muscle were rather similar to and sometimes even slightly higher than the corresponding levels in liver $\left(\mathrm{THg}_{\text {liver }} / \mathrm{THg}_{\text {muscle }}\right.$ ratio ranging from 0.55 to 1.4$)$. The liver-to-muscle ratio has already been used to identify the degree of $\mathrm{Hg}$ pollution in a specific ecosystem ( $\mathrm{THg}_{\text {liver }}$ / $\mathrm{THg}_{\text {muscle }}>1$ indicates an increase in $\mathrm{Hg}$ uptake). ${ }^{40,41}$ Similarly, significant differences were found between both tissue types in the case of the other environmentally relevant metals, with liver tissue generally showing much higher concentrations than muscle tissue. The $\mathrm{THg}$ concentrations observed in tusk from the fjords indicate an unusually high $\mathrm{Hg}$ intake, greatly affecting the liver as a vital organ owing to its key metabolic role in, e.g., $\mathrm{Hg}$ redistribution, excretion and/or detoxification. $^{23,42-44}$

Also $\mathrm{MeHg}$ levels revealed differences as a function of location and tissue type. Approximately $100 \%$ of the $\mathrm{Hg}$ present in muscle tissue of tusk was in the form of $\mathrm{MeHg}^{42}$ while in liver tissue only 14 to $52 \%$ of the $\mathrm{Hg}$ was in the form of $\mathrm{MeHg}$. For liver tissue of tusk, the lowest \% $\mathrm{MeHg}_{\text {liver }}$ corresponded with the most polluted area (Sørfjord), while the highest \% $\mathrm{MeHg}_{\text {liver }}$ was found for the least polluted area (Lofoten); assessment of the degree of pollution was based on the $\mathrm{THg}$ concentration in tusk. In fact, a negative correlation was found between $\mathrm{THg}$ and \% $\mathrm{MeHg}_{\text {liver }}$ (Spearman's correlation, $r=-0.786, p=0.021)$, indicating that a high degree of $\mathrm{Hg}$ pollution is accompanied by a low \% $\mathrm{MeHg}$ in tusk liver. A reduction of the $\mathrm{MeHg}$ fraction in fish tissues as a function of the amount of anthropogenic $\mathrm{Hg}$ was found to be in good agreement with previous literature on contaminated freshwater lakes and it can most likely be attributed to direct $\mathrm{iHg}$ intake and/or differences in $\mathrm{Hg}$ metabolism (e.g., higher $\mathrm{MeHg}$ demethylation rate $\left.^{41}\right)$ in heavily polluted areas. ${ }^{45}$ The differences in $\mathrm{Hg}$ speciation between liver and muscle tissue of tusk may stem from a different distribution of the different $\mathrm{Hg}$ compounds (iHg and $\mathrm{MeHg}$ ) (i) as originally taken up and/or (ii) as present after partial demethylation of $\mathrm{MeHg} .{ }^{23}$ Marine fish primarily accumulate $\mathrm{Hg}$ via the diet (mainly in the form of $\mathrm{MeHg}$ ), although some direct absorption via the gills, particularly in highly polluted areas, cannot be ruled out. ${ }^{46}$

When the ingested $\mathrm{Hg}$ has been absorbed in the intestine, it is transported through the bloodstream to vital organs, such as liver, which, along with the intestine, has been identified as a key organ for $\mathrm{MeHg}$ demethylation. ${ }^{28}$ The different $\mathrm{Hg}$ compounds can then be (partly) accumulated in the liver and/ or (partly) redistributed to other organs and tissues, such as muscle. $\mathrm{MeHg}$ can cross cellular membranes more readily compared to $\mathrm{iHg}$, allowing $\mathrm{MeHg}$ to reach the muscle tissue where it can bind tightly with cysteine-rich proteins. Therefore, muscle tissue acts as a reservoir of the $\mathrm{MeHg}$ resulting from the $\mathrm{MeHg}$ intake coming from the diet or the remaining $\mathrm{MeHg}$ after partial demethylation, while the $\mathrm{iHg}$ thus produced and/ or the iHg fraction directly introduced into the fish in highly polluted areas accumulates in liver tissue. The different accumulation patterns and the preferential excretion of $\mathrm{iHg}$ compared to $\mathrm{MeHg}$ explain the differences in $\mathrm{MeHg}$ fractions between liver and muscle tissues of tusk. ${ }^{23,46}$

In addition to $\mathrm{THg}$ concentration and $\mathrm{MeHg}$ speciation, the isotopic composition $\left(\delta^{199} \mathrm{Hg}, \delta^{200} \mathrm{Hg}, \delta^{201} \mathrm{Hg}, \delta^{202} \mathrm{Hg}, \Delta^{199} \mathrm{Hg}\right.$, $\Delta^{200} \mathrm{Hg}$, and $\Delta^{201} \mathrm{Hg}$ ) of $\mathrm{Hg}$ can provide added value (the $\mathrm{Hg}$ isotope ratio results are provided in Table $\mathrm{S} 8$ and are summarized in Figure 2). Figure 2A shows how $\delta^{202} \mathrm{Hg}$ (MDF) varies between the different locations and between the two tissue types, with values ranging from -1.32 to $0.17 \%$ for liver tissue (average of $-0.65 \%$ ) and from -0.54 to $1.00 \%$ o for muscle tissue (average of $0.35 \%$ ). Overall, significant
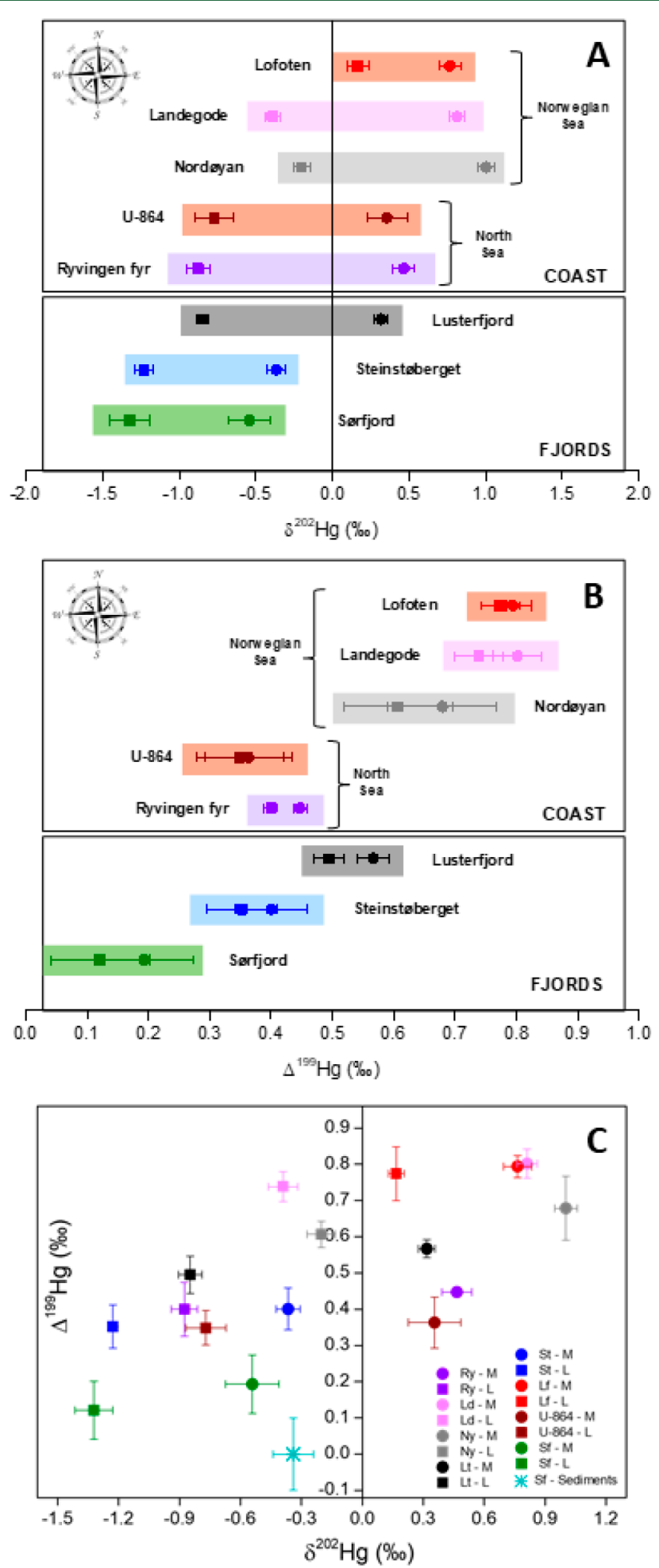

Figure 2. $\delta^{202} \mathrm{Hg}(\mathrm{A}), \Delta^{199} \mathrm{Hg}(\mathrm{B})$, and $\Delta^{199} \mathrm{Hg}$ vs $\delta^{202} \mathrm{Hg}(\%$ ) for liver (squares) and muscle (circles) tissues of tusk (Brosme brosme) for the different locations studied in this work. 
variations were observed between the different locations and between the two different tissue types. The lowest $\delta^{202} \mathrm{Hg}$ values correspond with the highest $\mathrm{Hg}$ concentrations (Sørfjord), while the highest $\delta^{202} \mathrm{Hg}$ values were found in the less polluted areas, i.e., Lofoten and Nordøyan; these two locations are situated on the Norwegian Sea coast, where a high level of $\mathrm{Hg}$ accumulation is not expected as it is relatively remote from most sources of $\mathrm{Hg}$ pollution. This suggests a certain correlation between $\delta^{202} \mathrm{Hg}$ values and $\mathrm{THg}$ concentrations. The existence of this correlation was indeed confirmed for liver (Spearman's correlation, $r=-0.786, p=$ 0.021 ), while such a correlation was not found for muscle (Figure S4). Liver tissue always showed a lower $\delta^{202} \mathrm{Hg}$ (more enriched in the lighter $\mathrm{Hg}$ isotopes) than the corresponding muscle tissue (by $1 \% 0$ on average). In a previous work, ${ }^{23}$ liver tissues of marine mammals (seals and whales) were also found to be enriched in the lighter $\mathrm{Hg}$ isotopes compared to muscle tissues. In this work, the difference in $\delta^{202} \mathrm{Hg}$ values between the two tissues $\left(\delta^{202} \mathrm{Hg}_{\text {muscle }}-\delta^{202} \mathrm{Hg}_{\text {liver }}\right)$ ranged from 0.60 to $1.34 \%$. These differences showed a clear negative correlation with the $\% \mathrm{MeHg}$ in liver for the coastal locations (Figure 3).

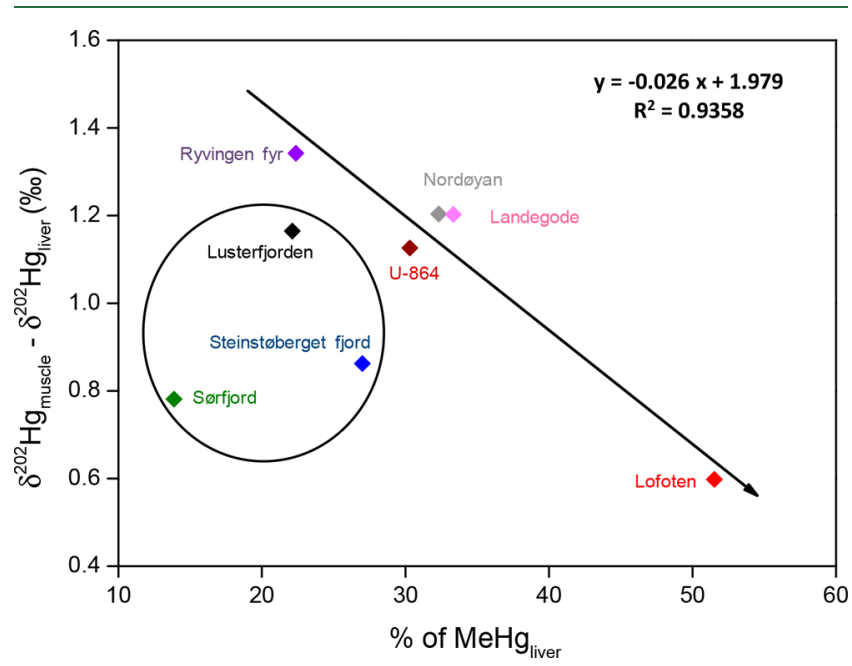

Figure 3. $\delta^{202} \mathrm{Hg}_{\text {muscle }}-\delta^{202} \mathrm{Hg}_{\text {liver }}$ as a function of the $\% \mathrm{MeHg}$ in liver for the eight locations studied in this work.

When fitting a straight line through the data for the coastal locations only, i.e., excluding the data for the three fjords, an $\mathrm{R}^{2}$ coefficient of 0.936 and a $p$-value of 0.007 were obtained. The deviation from the line for the fjord samples indicates the additional uptake of $\mathrm{iHg}$ and/or higher $\mathrm{Hg}$ demethylation rates with increased exposure, i.e., in heavily polluted areas. ${ }^{26,41}$

Study of the additional MIF affecting the odd-numbered isotopes of $\mathrm{Hg}$ (Figure S5) can shed some light onto the origin of the differences in $\mathrm{Hg}$ speciation and isotopic signatures for liver and muscle tissues of tusk. $\Delta^{199} \mathrm{Hg}$ as a function of location and tissue type ranged from 0.12 to $0.77 \%$ in liver tissue and from 0.19 to $0.80 \%$ in muscle tissue (Figure $2 \mathrm{~B}$ and Table S8). The $\Delta^{199} \mathrm{Hg}$ values were found to be related with the THg concentration, with a lower extent of MIF in the highest polluted areas (Sørfjord) and a higher degree of MIF in the two northernmost locations, Landegode and Lofoten. This was found to be in good agreement with the low MIF shown in heavily polluted areas. ${ }^{47}$ In contrast to the situation for MDF, no significant differences in $\Delta^{199} \mathrm{Hg}$ values between liver and muscle tissues were observed, barely affected by the location studied. The absence of significant differences in $\Delta^{199} \mathrm{Hg}$ values between liver and muscle of tusk from the same location suggests that in vivo metabolic processes, such as $\mathrm{MeHg}$ demethylation, are the underlying reason for the differences in $\mathrm{Hg}$ speciation and in $\delta^{202} \mathrm{Hg}$ values between both tissue types. Also the experimental $\Delta^{199} \mathrm{Hg} / \Delta^{201} \mathrm{Hg}$ ratio of $1.15 \pm 0.06$ (Figure S6) was found to be close to the value characteristic for $\mathrm{MeHg}$ photodegradation $(\sim 1.2) .{ }^{19}$ We observed a gradient in $\Delta^{199} \mathrm{Hg}$ from open ocean to the coast, suggesting that the $\mathrm{MeHg}$ has undergone different degrees of photodemethylation before it entered the food web. Therefore, the $\Delta^{201} \mathrm{Hg}$ values were used to estimate the $\%$ of $\mathrm{MeHg}$ photodegradated, with values ranging between 6 and 24\% (see the SI for further insights into the use of MIF $\mathrm{Hg}$ isotopic signatures). ${ }^{19,22,48-50}$

As indicated before, while in vivo demethylation of $\mathrm{MeHg}$ in mammals is accepted, for fish it is a matter of controversy. Perhaps the relatively high position of tusk within the food chain might be responsible for the differences observed between tusk and small fish species commonly used in feeding experiments. Thus, the differences in $\mathrm{Hg}$ isotopic composition between liver and muscle may result from in vivo metabolic processes, such as $\mathrm{MeHg}$ demethylation, and they are linked to a difference in $\mathrm{Hg}$ speciation between the two tissue types, greatly affecting the corresponding bulk $\mathrm{Hg}$ isotopic signatures (Figure S7). ${ }^{23}$ In addition, the mixture of $\mathrm{Hg}$ from various sources and/or of different $\mathrm{Hg}$ compounds (especially in highly polluted areas) cannot be ruled out, although based on the consistency of the $\Delta^{199} \mathrm{Hg}$ values between both tissues of tusk from the same location (see below), this possibility is rather unlikely.

Potential Links between Mercury Occurrence in Tusk and Anthropogenic Sources. Since the level of THg in tusk muscle (the edible part) exceeded the European limits (established at $0.5 \mathrm{mg} \mathrm{kg}^{-1}$ (w.w.) $)^{51}$ in five of the eight locations studied in this work, i.e., in all of the fjord locations and in two of the five coastal locations (Ryvingen fyr and Landegode), the link between potential anthropogenic $\mathrm{Hg}$ sources and the occurrence of mercury in liver and muscle tissues of tusk was assessed. As a result of their specific topography (e.g., poorer water circulation and/or higher contribution of natural terrestrial runoff), elevated concentrations of $\mathrm{Hg}$ (and other pollutants) are expected for fjord locations compared to coastal and open ocean areas. In this work, this was observed for fish tissues from these fjords, although at an even higher extent in the case of the Sørfjord, which can be attributed to a higher input from anthropogenic $\mathrm{Hg}$ sources at this location.

Two well-established $\mathrm{Hg}$ sources were hypothesized to be related with the occurrence of $\mathrm{Hg}$ in tusk from the Sørfjord and U-864 locations (fjord and open ocean area, respectively). In previous works, high local $\mathrm{Hg}$ pollution was reported in fish, soils and mushrooms from the surroundings of the Sørfjord location. ${ }^{7,52-55}$ This was mainly attributed to the direct impact of a $\mathrm{Zn}$ smelter located in Odda, a small town situated at the southern end of the Sørfjord, since $\mathrm{Hg}$ is an important associated element in $\mathrm{Zn}$ ores. ${ }^{56}$ Thus, $\mathrm{Hg}$ contamination in this area may stem from byproducts of the roasting process of $\mathrm{Zn}$ ores, e.g., atmospheric emission of $\mathrm{Hg}^{0}$ and/or $\mathrm{Hg}^{2+}$ and subsequent deposition, and/or (accidental) release of contamination into the fjord water e.g., during unloading of $\mathrm{Zn}$ ore material at the dock or by residues from the smelting process. $^{56-59}$ In this work, the highest $\mathrm{THg}$ concentrations in liver and muscle tissues of tusk were found in the Sørfjord, while tusk livers also showed significantly higher concen- 
trations of $\mathrm{Pb}$ than for the other locations (5-10-fold higher), illustrating the anthropogenic pollution affecting this area. In addition, a 2-fold higher concentration of $\mathrm{Zn}$ was observed compared to all the other locations, supporting the influence of the $\mathrm{Zn}$ smelter located in Odda on the fjord ecosystem. This elevated concentration of $\mathrm{Hg}$ and other metals, such as $\mathrm{Pb}$ and $\mathrm{Zn}$, was also found in fish and sediments from other ecosystems affected by smelting and mining activities. ${ }^{60-62}$ Also, the low \% MeHg in liver (14\%) pointed to an anomalously high $\mathrm{Hg}$ pollution, as discussed in the previous section.

In addition, the lowest $\delta^{202} \mathrm{Hg}(-1.32 \pm 0.09$ and $-0.54 \pm$ $0.13 \%$, for liver and muscle, respectively) and $\Delta^{199} \mathrm{Hg}(0.12$ \pm 0.08 and $0.19 \pm 0.08 \%$ o for liver and muscle, respectively) were found in the Sørfjord. $\Delta^{199} \mathrm{Hg}$ values tend to be low in highly polluted areas owing to the large amount of anthropogenic $\mathrm{iHg}^{47}$ With the $\mathrm{Zn}$ smelter located in Odda as the main source of $\mathrm{Hg}$ pollution within the Hardangerfjord, tusk collected in the Sørfjord will most likely be affected to a higher extent because of the closeness to the contamination source. During $\mathrm{Zn}$ ore roasting, $\mathrm{Hg}$ present in the ore is fractionated, resulting in different $\mathrm{Hg}$ compounds with varying isotopic signatures, e.g., solid waste enriched in the heavier $\mathrm{Hg}$ isotopes and emissions of lighter $\mathrm{Hg}^{0}$ and/or $\mathrm{Hg}^{2+}$ to the atmosphere. ${ }^{58,63}$ Thus, the $\mathrm{Hg}$ isotopic signatures of liver and muscle tissues of tusk can be the result of (i) mixing of $\mathrm{Hg}$ from multiple sources, such as direct release into the seawater, atmospheric deposition and/or freshwater runoff and of (ii) different in vivo metabolic processes and their associated variations in the isotopic composition. In order to assess the influence of the $\mathrm{Zn}$ smelter, marine bottom sediments were collected from an area close to where $\mathrm{Zn}$ ore was unloaded and waste material was collected. These sediments were found to be strongly affected by $\mathrm{Hg}$ contamination $\mathrm{THg}$ concentration of $1.40 \pm 0.25 \mathrm{mg} \mathrm{kg}^{-1}$ ), and isotopic analysis of $\mathrm{Hg}$ showed $\delta^{202} \mathrm{Hg}$ and $\Delta^{199} \mathrm{Hg}$ values of $-0.34 \pm 0.04$ and $0.00 \pm 0.03$ $\%$, respectively. These values were found to be similar (both for MDF and MIF) to those reported on in literature for sediments impacted by a $\mathrm{Zn}$ smelter via atmospheric deposition, and contaminated with byproducts of ore roasting (e.g., $\mathrm{Hg}$ waste calcine) and/or mining. ${ }^{58,61,64,65}$ In this work, slightly more negative $\delta^{202} \mathrm{Hg}$ values were obtained for muscle tissue of tusk from the Sørfjord location relative to the sediments collected near the Zn smelter (Figure 2C), which can be explained by the net MDF accompanying the methylation and demethylation processes. ${ }^{66,67}$ The small differences in $\Delta^{199} \mathrm{Hg}$ values can be explained by the input of iHg from atmospheric deposition and/or the contribution of the diet in an open marine $\mathrm{Hg}$ isotope composition, i.e., $\mathrm{MeHg}$ with high $\Delta^{199} \mathrm{Hg}$ anomalies. Thus, on the basis of the $\mathrm{Hg}$ isotope ratio results obtained in this work, the $\mathrm{Hg}$ pollution affecting the tusks collected at the Sørfjord location can most likely be attributed to the impact of the $\mathrm{Zn}$ smelter.

In the case of Steinstøberget (outer part of the Hardangerfjord), $\delta^{202} \mathrm{Hg}$ values $(-1.23 \pm 0.02$ and $-0.37 \pm$ $0.06 \%$, for liver and muscle, respectively) also pointed toward contamination from the $\mathrm{Zn}$ smelter as the main source of $\mathrm{Hg}$ pollution. This can most likely be attributed to the water current going from the inner to the outer part of the Hardangerfjord and to the predominant winds going from south to north in this area (i.e., following the direction of the fjord as shown in Figure 1). ${ }^{53}$ However, the slightly higher $\Delta^{199} \mathrm{Hg}$ values $(0.35 \pm 0.06$ and $0.40 \pm 0.06 \%$ o for liver and muscle, respectively) seem to indicate a lower impact from the smelter, while the Sørfjord (with depths of $\sim 350 \mathrm{~m}$ ) and Steinstøberget (with depths of $\sim 150 \mathrm{~m}$ ) also show a difference in depth; Figure S8 shows the $\Delta^{199} \mathrm{Hg}$ values and the depth at which the tusks were caught for all the locations studied in this work.

As indicated above, from the eight locations studied, three areas did not show a high level of $\mathrm{Hg}$ pollution. Surprisingly, the U-864 location was found to be one of them. The U-864 is a German submarine that was carrying 67 tons of metallic $\mathrm{Hg}$ in its keel when it was torpedoed and sunk in the proximity of Bergen (Norway) at the end of World War II. ${ }^{35,68}$ The U-864 $\mathrm{Hg}$ contaminated the surrounding sediments with metallic $\mathrm{Hg}{ }^{69}$ but it is not clear yet whether this $\mathrm{Hg}$ has entered the food web. In a previous work from the same authors, ${ }^{35} \mathrm{Hg}$ isotopic analysis of brown crab (Cancer pagurus) tissues showed that $\delta^{202} \mathrm{Hg}$ values in the brown meat (predominantly consisting of the digestive system and the gonads) of crabs from the wreck location were shifted toward the isotopic signature of the metallic $\mathrm{Hg}$ collected at the vicinity of the submarine wreckage, while such differences were not found for claw (muscle) meat (Figure S9). This shift in the Hg isotopic signature was hypothesized to be related with the feeding habits of this crab species, allowing for direct ingestion of metallic $\mathrm{Hg}$. On the basis of (i) the $\mathrm{THg}$ and $\mathrm{MeHg}$ concentrations, (ii) $\mathrm{THg}_{\text {liver }} / \mathrm{THg}_{\text {muscle }}$ ratio, and (iii) $\% \mathrm{MeHg}$ in liver, of tusks from the U-864 location, we did not find any evidence of anomalously high degree of $\mathrm{Hg}$ pollution at this location. This can be attributed to the lower methylation rate of metallic $\mathrm{Hg}$ (if any at the location studied) compared to that of $\mathrm{Hg}^{2+} \cdot{ }^{70,71} \delta^{202} \mathrm{Hg}$ values for liver and muscle of tusks from the U-864 location were also compared to those obtained for crab tissues (Figure S9). In contrast to the previous work, the $\mathrm{Hg}$ isotopic signatures of liver and muscle of tusk do not seem to be affected by those of contaminated sediments from the wreck location and/or with that of metallic $\mathrm{Hg}$ from the submarine. Furthermore, no significant differences in $\delta^{202} \mathrm{Hg}$ and $\Delta^{199} \mathrm{Hg}$ values were found between tusk from the U-864 location and from Ryvingen fyr. It needs to be noted that higher $\mathrm{Hg}$ pollution was found for Ryvingen fry (the location further south in the North Sea) compared to the U-864 location, and that the oceanic currents flowing from south to north in this area are not expected to allow the transport of the $\mathrm{U}-864 \mathrm{Hg}$ from the wreck site to the Ryvingen fyr location. On the basis of the aforementioned results, we suggest that, so far, the metallic $\mathrm{Hg}$ from the U-864 wreckage has not entered the food chain.

In addition to the three fjords, higher concentrations of $\mathrm{Hg}$ in tusk from Ryvingen fyr and Landegode were found compared to that of the other coastal locations. The differences between these two locations and the other three locations displaying $\mathrm{Hg}$ concentrations below the allowable limit might be related to the higher input of $\mathrm{Hg}$ coming from other $\mathrm{Hg}$ sources and transported by oceanic currents. For instance, $\mathrm{Hg}$ transported from the areas of Denmark and Oslo could elevate the level of $\mathrm{Hg}$ at Ryvingen fyr, while at Landegode, $\mathrm{Hg}$ could accumulate as a result of geographical constraints, limiting the circulation of water and hampering the removal of discharged waste (Figure 1). A further evaluation of the $\mathrm{Hg}$ isotopic signatures of tusk from the different locations seems to indicate the occurrence of three groups (Figure 2). These groups correspond with the two locations of (i) the Hardangenfjord (the Sørfjord and Steinstøberget), (ii) the two locations in the 
North Sea (U-864 and Ryvingen fyr), and (iii) the three locations in the Norwegian Sea (Nørdoyan, Landegode and Lofoten). Within the same group, the $\mathrm{Hg}$ isotopic composition of muscle was found to be more consistent than that of liver.

Selection of Fish Tissue for Monitoring Mercury Exposure. Addressing the appropriate tissue type(s) is a crucial issue for $\mathrm{Hg}$ monitoring programs. However, the selection of the best suited organ/tissue still remains challenging, especially given the dynamics of $\mathrm{Hg}$ within the different body compartments, their different affinities toward the respective $\mathrm{Hg}$ compounds and/or the occurrence of in vivo metabolic processes. ${ }^{41}$ To address and/or minimize these issues, liver and muscle tissues of tusks from different locations have been measured in this work for their $\mathrm{THg}$ and $\mathrm{MeHg}$ concentrations and $\mathrm{Hg}$ isotope ratios, a combination that allowed one to do the following:

- use the $\mathrm{THg}_{\text {liver }} / \mathrm{THg}_{\text {muscle }}$ ratio or liver/muscle index to identify heavily contaminated areas,

- assess the degree of $\mathrm{Hg}$ pollution by measuring the \% $\mathrm{MeHg}$ in liver (also the \% $\mathrm{MeHg}$ in muscle has been reported on for this purpose),

- provide insight into in vivo MDF and metabolic processes, such as $\mathrm{MeHg}$ demethylation, based on the comparison between $\delta^{202} \mathrm{Hg}$ for liver and muscle tissues, and

- evaluate the absence of in vivo MIF relying on the differences in $\Delta^{199} \mathrm{Hg}$ for liver and muscle, therefore providing additional information on different sources of pollution and/or different $\mathrm{Hg}$ compounds that can be characterized by a different degree of MIF.

Obviously, the measurement of different tissue types provides further information, but also increases the cost and time of the monitoring program. Therefore, it is important to realize the type of information provided by analyzing specific tissue types and the corresponding limitations. Liver is a highly responsive organ toward $\mathrm{iHg}$ exposure and is a target organ for contaminants, or in other words, it is able to accumulate higher $\mathrm{Hg}$ concentrations than other tissues. Liver also plays an important role in $\mathrm{Hg}$ detoxification and $\mathrm{Hg}$ metabolism, and is one of the key organs responsible of $\mathrm{MeHg}$ demethylation and subsequent redistribution of the two main forms of $\mathrm{Hg}$. Thus, $\mathrm{iHg}$ in liver can originate from direct uptake by the organism and/or from the demethylation of $\mathrm{MeHg}$. Given its importance, changes in $\mathrm{Hg}$ exposure are generally reflected first in the liver before they are evidenced in other organs and tissues, such as muscle. Some studies have indicated the faster turnover of this organ upon exposure and have noted the faster re-equilibration of the $\mathrm{Hg}$ isotopic signatures, thus better retaining the source signatures. ${ }^{72-74}$ However, the occurrence of in vivo metabolic processes, such as $\mathrm{MeHg}$ demethylation, and the associated isotope fractionation might hide or completely erase the original source signature. ${ }^{74}$ Because of this reason, Masbou et al. ${ }^{44}$ suggested that liver $\delta^{202} \mathrm{Hg}$ is not a suitable tissue/tracer, as it is strongly influenced by hepatic metabolic MDF, and recommended the use of liver $\Delta^{199} \mathrm{Hg}$ owing to the absence of in vivo MIF and the capability to preserve the isotopic signatures. However, muscle is the target tissue for $\mathrm{MeHg}$ accumulation and the main reservoir of this highly toxic $\mathrm{Hg}$ species, but it is not a good site for $\mathrm{iHg}$ deposition. ${ }^{42}$ Muscle is characterized by a slower response toward sudden changes in $\mathrm{Hg}$ concentrations and reflects the $\mathrm{Hg}$ accumulated over a longer period of exposure, making it less sensitive to immediate changes in $\mathrm{Hg}$ exposure. ${ }^{40,41,74}$ These differences between both tissue types have also been observed during this work, in which a higher degree of variability of the $\mathrm{Hg}$ isotopic signatures of tusk livers was found compared to that of muscles, thus pointing to the more sensitive behavior of liver as a response toward $\mathrm{Hg}$ exposure. Muscle tissue was found to be more consistent between groups, which was especially visible for the locations from the Norwegian Sea.

Although the following conclusions need to be handled with care due to the complexity of the biogeochemical $\mathrm{Hg}$ cycle and of each specific marine ecosystem, liver might be seen as the preferred organ of study when $\mathrm{Hg}$ contamination stems from inorganic forms, while one may assume that muscle is to be recommended to assess organic $\mathrm{Hg}$ pollution due to the storage capabilities of this tissue. However, in vivo metabolic processes occurring within the fish body can strongly influence the $\mathrm{Hg}$ finally stored in the muscle, and it is therefore important to investigate all these processes into a greater detail. It also needs to be noted that muscle is the edible part and its study is thus of high interest for seafood safety. In addition to the different $\mathrm{Hg}$ species, muscle can be recommended for lightly contaminated areas $\left(\mathrm{THg}_{\text {muscle }}>\mathrm{THg}_{\text {liver }}\right)$, while for heavily polluted locations, liver tissues provide additional information. ${ }^{40}$

Overall, important knowledge gaps still remain in our understanding of the biogeochemical $\mathrm{Hg}$ cycle, but elemental, speciation and isotopic analysis of $\mathrm{Hg}$ in (i) different species collected at the same location, (ii) the same species collected at different locations, and especially (iii) in different tissues of a selected species, seem to be a powerful approach for dealing with this important environmental and human threat.

\section{ASSOCIATED CONTENT}

\section{S Supporting Information}

The Supporting Information is available free of charge on the ACS Publications website at DOI: 10.1021/acs.est.8b04706.

Figures S1-S9 and Tables S1-S8; elemental analysis protocol; $\mathrm{Hg}$ isotopic analysis protocol; determination of other environmentally relevant metals in tusk; and $\Delta^{199} \mathrm{Hg} / \Delta^{201} \mathrm{Hg}$ ratios and estimation of the extent of $\mathrm{MeHg}$ photodegradation before its incorporation to the aquatic food web (PDF)

\section{AUTHOR INFORMATION}

\section{Corresponding Author}

*Phone: +3292644848; fax: +3292644960; e-mail: Frank. Vanhaecke@UGent.be.

\section{ORCID}

Frank Vanhaecke: 0000-0002-1884-3853

\section{Present Address}

${ }^{\#}$ University of Bergen, Faculty of Mathematics and Natural Sciences, Allégaten 41, 5020 Bergen, Norway.

\section{Author Contributions}

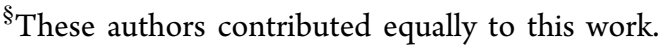

Notes

The authors declare no competing financial interest.

\section{ACKNOWLEDGMENTS}

All authors would like to acknowledge the Norwegian Coastal Administration, the Norwegian Food Safety Authority and the 
Norwegian Ministry of Trade, Industry and Fisheries for financial support. E.B.-F. thanks BOF-UGent for his postdoctoral grant. The authors also would like to thank $\mathrm{PhD}$ student Atabak Mahjour Azad for using tusk samples he collected in the Sørfjord and Lusterfjord.

\section{REFERENCES}

(1) Lamborg, C. H.; Hammerschmidt, C. R.; Bowman, K. L.; Swarr, G. J.; Munson, K. M.; Ohnemus, D. C.; Lam, P. J.; Heimbürger, L.-E.; Rijkenberg, M. J. A.; Saito, M. A. A global ocean inventory of anthropogenic mercury based on water column measurements. Nature 2014, 512, 65-69.

(2) Driscoll, C. T.; Mason, R. P.; Chan, H. M.; Jacob, D. J.; Pirrone, N. Mercury as a Global pollutant: Sources, Pathways, and Effects. Environ. Sci. Technol. 2013, 47, 4967-4983.

(3) Sandberg, M. G.; Volden, G. H.; Aarhus, I. J.; Hofman, M.; Olafsen, T. Betydningen av Fiskeri-og Havbruksnceringen for Norge $i$ 2008-en Ringvirkningsanalyse (The Importance of the Fisheries and Aquaculture Sector for Norway in 2008-An Analysis of Spillover Effects); SINTEF: Trondheim, 2010.

(4) Chen, C.; Amirbahman, A.; Fisher, N.; Harding, G.; Lamborg, C.; Nacci, D.; Taylor, D. Methylmercury in Marine Ecosystems: Spatial Patterns and Processes of Production, Bioaccumulation and Biomagnification. EcoHealth 2008, 5, 399-408.

(5) Bowering, W. R.; Nedreaas, K. H. Age validation and growth of Greenland halibut (Reinhardtius hippoglossoides (Walbaum)): A comparison of populations in the Northwest and Northeast Atlantic. Sarsia 2001, 86, 53-68.

(6) Sandberg, P.; Steinseide, A. K. Economic and biological figures from Norwegian fisheries - 2016 2017, 38.

(7) Kvangarsnes, K.; Frantzen, S.; Julshamn, K.; Sæthre, L. J.; Nedreaas, K.; Maage, A. Distrubution of Mercury in a Gadoid Fish Species, Tusk (Brosme brosme), and Its Implication for Food Safety. J. Food Sci. Eng. 2012, 2, 603-615.

(8) Frantzen, S.; Maage, A. Fremmedstoffer i Villfisk Med Vekt på Kystneere Farvann. Brosme Lange og Bifangstarter; Gjelder Tall for Prøver Samlet Inn i 2013-2015; NIFES: Bergen, 2016; 115.

(9) Maage, A.; Bjell, O.; Olsvik, P.; Nilsen, B.; Julshamn, K., Contaminants in fish and seafood products 2011. Miljøgifter $i$ Fisk og Fiskevarer 2011: Kvikksølv i Djupvassfisk og Skaldyr frå Hardangerfjorden samt Miljogifter i Marine Oljer, NIFES Report; In Norwegian, Summary in English, Bergen, 2012, pp 1-31.

(10) Yin, R.; Feng, X.; Shi, W. Application of the stable-isotope system to the study of sources and fate of $\mathrm{Hg}$ in the environment: A review. Appl. Geochem. 2010, 25, 1467-1477.

(11) Blum, J. D.; Sherman, L. S.; Johnson, M. W. Mercury Isotopes in Earth and Environmental Sciences. Annu. Rev. Earth Planet. Sci. 2014, 42, 249-269.

(12) Wiederhold, J. G.; Cramer, C. J.; Daniel, K.; Infante, I.; Bourdon, B.; Kretzschmar, R. Equilibrium Mercury Isotope Fractionation between Dissolved $\mathrm{Hg}$ (II) Species and Thiol-Bound Hg. Environ. Sci. Technol. 2010, 44, 4191-4197.

(13) Jiskra, M.; Wiederhold, J. G.; Bourdon, B.; Kretzschmar, R. Solution Speciation Controls Mercury Isotope Fractionation of $\mathrm{Hg}(\mathrm{II})$ Sorption to Goethite. Environ. Sci. Technol. 2012, 46, 66546662.

(14) Estrade, N.; Carignan, J.; Sonke, J. E.; Donard, O. F. X. Mercury isotope fractionation during liquid-vapor evaporation experiments. Geochim. Cosmochim. Acta 2009, 73, 2693-2711.

(15) Ghosh, S.; Schauble, E. A.; Couloume, G. L.; Blum, J. D.; Bergquist, B. A. Estimation of nuclear volume dependent fractionation of mercury isotopes in equilibrium liquid-vapor evaporation experiments. Chem. Geol. 2013, 336, 5-12.

(16) Rodríguez-González, P.; Epov, V. N.; Bridou, R.; Tessier, E.; Guyoneaud, R.; Monperrus, M.; Amouroux, D. Species-Specific Stable Isotope Fractionation of Mercury during $\mathrm{Hg}$ (II) Methylation by and Anaerobic Bacteria (Desulfobulbus propionicus) under Dark Conditions. Environ. Sci. Technol. 2009, 43, 9183-9188.
(17) Perrot, V.; Bridou, R.; Pedrero, Z.; Guyoneaud, R.; Monperrus, M.; Amouroux, D. Identical Hg Isotope Mass Dependent Fractionation Signature during Methylation by Sulfate-Reducing Bacteria in Sulfate and Sulfate-Free Environment. Environ. Sci. Technol. 2015, 49, 1365-1373.

(18) Kritee, K.; Blum, J. D.; Barkay, T. Mercury Stable Isotope Fractionation during Reduction of $\mathrm{Hg}(\mathrm{II})$ by Different Microbial Pathways. Environ. Sci. Technol. 2008, 42, 9171-9177.

(19) Bergquist, B. A.; Blum, J. D. Mass-Dependent and -Independent Fractionation of $\mathrm{Hg}$ Isotopes by Photoreduction in Aquatic Systems. Science 2007, 318, 417-420.

(20) Malinovsky, D.; Latruwe, K.; Moens, L.; Vanhaecke, F. Experimental study of mass-independence of $\mathrm{Hg}$ isotope fractionation during photodecomposition of dissolved methylmercury. J. Anal. At. Spectrom. 2010, 25, 950-956.

(21) Zheng, W.; Hintelmann, H. Isotope Fractionation of Mercury during Its Photochemical Reduction by Low-Molecular-Weight Organic Compounds. J. Phys. Chem. A 2010, 114, 4246-4253.

(22) Sherman, L. S.; Blum, J. D.; Franzblau, A.; Basu, N. New Insight into Biomarkers of Human Mercury Exposure Using Naturally Occurring Mercury Stable Isotopes. Environ. Sci. Technol. 2013, 47, 3403-3409.

(23) Perrot, V.; Masbou, J.; Pastukhov, M. V.; Epov, V. N.; Point, D.; Bérail, S.; Becker, P. R.; Sonke, J. E.; Amouroux, D. Natural Hg isotopic composition of different $\mathrm{Hg}$ compounds in mammal tissues as a proxy for in vivo breakdown of toxic methylmercury. Metallomics 2016, 8, 170-178.

(24) Kwon, S. Y.; Blum, J. D.; Carvan, M. J.; Basu, N.; Head, J. A.; Madenjian, C. P.; David, S. R. Absence of Fractionation of Mercury Isotopes during Trophic Transfer of Methylmercury to Freshwater Fish in Captivity. Environ. Sci. Technol. 2012, 46, 7527-7534.

(25) Gonzalez, P.; Dominique, Y.; Massabuau, J. C.; Boudou, A.; Bourdineaud, J. P. Comparative effects of dietary methylmercury on gene expression in liver, skeletal muscle, and brain of the zebrafish (Danio rerio). Environ. Sci. Technol. 2005, 39, 3972-3980.

(26) Feng, C.; Pedrero, Z.; Gentès, S.; Barre, J.; Renedo, M.; Tessier, E.; Berail, S.; Maury-Brachet, R.; Mesmer-Dudons, N.; Baudrimont, M.; Legeay, A.; Maurice, L.; Gonzalez, P.; Amouroux, D. Specific Pathways of Dietary Methylmercury and Inorganic Mercury Determined by Mercury Speciation and Isotopic Composition in Zebrafish (Danio rerio). Environ. Sci. Technol. 2015, 49, 1298412993.

(27) Wang, X.; Wang, W.-X. Selenium induces the demethylation of mercury in marine fish. Environ. Pollut. 2017, 231, 1543-1551.

(28) Wang, X.; Wu, F.; Wang, W.-X. In Vivo Mercury Demethylation in a Marine Fish (Acanthopagrus schlegeli). Environ. Sci. Technol. 2017, 51, 6441-6451.

(29) Jackson, T. A. Isotopic and Chemical Characteristics of Mercury in Organs and Tissues of Fish in a Mercury-Polluted Lake: Evidence for Fractionation of Mercury Isotopes by Physiological Processes. Environ. Toxicol. Chem. 2018, 37, 515-529.

(30) Sonke, J. E. A global model of mass independent mercury stable isotope fractionation. Geochim. Cosmochim. Acta 2011, 75, 45774590.

(31) Bigeleisen, J. Nuclear Size and Shape Effects in Chemical Reactions. Isotope Chemistry of the Heavy Elements. J. Am. Chem. Soc. 1996, 118, 3676-3680.

(32) Buchachenko, A. L. Magnetic Isotope Effect: Spin Control of Chemical Reactions. J. Phys. Chem. A 2001, 105, 9995-10011.

(33) Epov, V. N.; Malinovskiy, D.; Vanhaecke, F.; Bégué, D.; Donard, O. F. X. Modern mass spectrometry for studying massindependent fractionation of heavy stable isotopes in environmental and biological sciences. J. Anal. At. Spectrom. 2011, 26, 1142-1156.

(34) Malinovsky, D.; Vanhaecke, F. Mass-independent isotope fractionation of heavy elements measured by MC-ICP-MS: a unique probe in enviromental sciences. Anal. Bioanal. Chem. 2011, 400, $1619-1624$

(35) Rua-Ibarz, A.; Bolea-Fernandez, E.; Maage, A.; Frantzen, S.; Valdersnes, S.; Vanhaecke, F. Assessment of $\mathrm{Hg}$ Pollution Released 
from a WWII Submarine Wreck (U-864) by Hg Isotopic Analysis of Sediments and Cancer pagurus Tissues. Environ. Sci. Technol. 2016, 50, 10361-10369.

(36) Rua-Ibarz, A.; Bolea-Fernandez, E.; Vanhaecke, F. An in-depth evaluation of accuracy and precision in $\mathrm{Hg}$ isotopic analysis via pneumatic nebulization and cold vapor generation multi-collector ICP-mass spectrometry. Anal. Bioanal. Chem. 2016, 408, 417-429.

(37) Valdersnes, S.; Maage, A.; Fliegel, D.; Julshamn, K. A Method for the Routine Determination of Methylmercury in Marine Tissue by GC Isotope Dilution-ICP-MS. J. AOAC Int. 2012, 95, 1189-1194.

(38) Baxter, D. C.; Rodushkin, I.; Engström, E.; Malinovsky, D. Revised exponential model for mass bias correction using and internal standard for isotope abundance ratio measurements by multi-collector inductively coupled plasma mass spectrometry. J. Anal. At. Spectrom. 2006, 21, 427-430.

(39) Manzetti, S.; Stenersen, J. H. V. A critical view of the environmental conditionof the Sognefjord. Mar. Pollut. Bull. 2010, 60, $2167-2174$.

(40) Goldstein, R. M.; Brigham, M. E.; Stauffer, J. C. Comparison of mercury concentrations in liver, muscle, whole bodies, and composites of fish from the Red River of the North. Can. J. Fish. Aquat. Sci. 1996, 53, 244-252.

(41) Cizdziel, J.; Hinners, T.; Cross, C.; Pollard, J. Distribution of mercury in the tissues of five species of freshwater fish from Lake Mead, USA. J. Environ. Monit. 2003, 5, 802-807.

(42) Régine, M.-B.; Gilles, D.; Yannick, D.; Alain, B. Mercury distribution in fish organs and food regimes: Significant relationships from twelve species collected in French Guaiana (Amazonian basin). Sci. Total Environ. 2006, 368, 262-270.

(43) Leaner, J. J.; Mason, R. P. The effect of thiolate organic compounds on methylmercury accumulation and redistribution in sheepshead minnows. Environ. Toxicol. Chem. 2001, 20, 1557-1563.

(44) Masbou, J.; Sonke, J. E.; Amouroux, D.; Guillou, G.; Becker, P. R.; Point, D. Hg-Stable Isotope Variations in Marine Top Predators of the Western Artic Ocean. ACS Earth Space Chem. 2018, 2, 479-490.

(45) Perrot, V.; Epov, V. N.; Pastukhov, M. V.; Grebenshchikova, V. I.; Zouiten, C.; Sonke, J. E.; Husted, S.; Donard, O. F. X.; Amouroux, D. Tracing Sources and Bioaccumulation of Mercury in Fish of Lake Baikal - Angara River using Hg Isotopic Composition. Environ. Sci. Technol. 2010, 44, 8030-8037.

(46) Pickhardt, P. C.; Stepanova, M.; Fisher, N. S. Contrasting uptake routes and tissue distributions of inorganic and methylmercury in mosquitofish (Gambusia affinis) and redear sunfish (Lepomis microlophus). Environ. Toxicol. Chem. 2006, 25, 2132-2142.

(47) Kwon, S. Y.; Blum, J. D.; Chen, C. Y.; Meattey, D. E.; Mason, R. P. Mercury Isotope Study of Sources and Exposure Pathways of Methylmercury in Estuarine Food Webs in the Northeastern U.S. Environ. Sci. Technol. 2014, 48, 10089-10097.

(48) Gantner, N.; Hintelmann, H.; Zheng, W.; Muir, D. C. Variations in Stable Isotope Fractionation of hg in Food Webs of Artic Lakes. Environ. Sci. Technol. 2009, 43, 9148-9154.

(49) Senn, D. B.; Chesney, E. J.; Blum, J. D.; Bank, M. S.; Maage, A.; Shine, J. P. Stable Isotope (N, C, Hg) Study of Methylmercury Sources and Trophic Transfer in the Northern Gulf of Mexico. Environ. Sci. Technol. 2010, 44, 1630-1637.

(50) Perrot, V.; Pastukhov, M. V.; Epov, V. N.; Husted, S.; Donard, O. F. X.; Amouroux, D. Higher Mass-Independent Isotope Fractionation of Methylmercury in the Pelagic Food Web of Lake Baikal (Russia). Environ. Sci. Technol. 2012, 46, 5902-5911.

(51) European Commission, Setting maximum levels for certain contaminants in food stuffs, Commission Regulation (EC) No 466/ 20012001.

(52) Ruus, A.; Green, N. W. Monitoring the Envrionmental Quality in the Sørfjord 2006. Contaminants in Organisms. Overvåking av Miljøforholdene i Søfjorden 2006, Delrapport 3, Miljøgifter i Organismer, Norsk Institutt for Vannforskning. In Norwegian, Summary in English, Oslo, 2007, pp 23-24.

(53) Svendsen, M. L.; Steinnes, E.; Blom, H. A. Vertical and Horizontal Distributions of $\mathrm{Zn}, \mathrm{Cd}, \mathrm{Pb}, \mathrm{Cu}$, and $\mathrm{Hg}$ in Uncultivated
Soil in the Vicinity of a Zinc Smelter at Odda, Norway. Soil Sediment Contam. 2007, 16, 585-603.

(54) Ruus, A.; Skeí, J.; Green, N.; Schøyen, M. Monitoring the Envrionmental Quality in the Sørfjord 2009. Contaminants in Organisms. Overvåking av Miljøforholdene i Søfjorden 2009. Metaller i Vannmassene, Miljøgifter i Organismer. Rapport til KLIF, NIVA-rapport 6018-2010. In Norwegian, Summary in English, Oslo, 2010, pp 1-92.

(55) Olsvik, P. A.; Lindgren, M.; Maage, A. Mercury contamination in deep-water fish: Transcriptional responses in tusk (Brosme brosme) from a fjord gradient. Aquat. Toxicol. 2013, 144-145, 172-185.

(56) Wang, S. X.; Song, J. X.; Li, G. H.; Wu, Y.; Zhang, L.; Wan, Q.; Streets, D. G.; Chin, C. K.; Hao, J. M. Estimating mercury emissions from a zinc smelter in relation to China's mercury control policies. Environ. Pollut. 2010, 158, 3347-3353.

(57) Hylander, L. D.; Herbert, R. B. Global Emission and Production of Mercury during the Pyrometallurgical Extraction of Nonferrous Sulfide Ores. Environ. Sci. Technol. 2008, 42, 5971-5977.

(58) Sonke, J. E.; Schäfer, J.; Chmeleff, J.; Audry, S.; Blanc, G.; Dupré, B. Sedimentary mercury stable isotope records of atmospheric and riverine pollution from two major European heavy metal refineries. Chem. Geol. 2010, 279, 90-100.

(59) Masbou, J.; Point, D.; Sonke, J. E. Application of a selective extraction method for methylmercury compound specific stable isotope analysis (MeHg-CSIA) in biological materials. J. Anal. At. Spectrom. 2013, 28, 1620-1628.

(60) Harrison, S. E.; Klaverkamp, J. F. Metal contamination in liver and muscle of northern pike (Esox lucius) and white suckers (Catostomus commersoni) and in sediments from lakes near the smelter at Flin Flon, Manitoba. Environ. Toxicol. Chem. 1990, 9, 941956.

(61) Ma, J.; Hintelmann, H.; Kirk, J. L.; Muir, D. C. G. Mercury concentrations and mercury isotope composition in lake sediment cores from the vicinity of a metal smelting facility in Flin Flon, Manitoba. Chem. Geol. 2013, 336, 96-102.

(62) Sun, R.; Sonke, J. E.; Heimbürger, L.-E.; Belkin, H. E.; Liu, G.; Shome, D.; Cukrowska, E.; Liousse, C.; Pokrovsky, O. S.; Streets, D. G. Mercury Stable Isotope Signatures of World Coal Deposits and Historical Coal Combustion Emissions. Environ. Sci. Technol. 2014, 48, 7660-7668.

(63) Yin, R.; Feng, X.; Wang, J.; Li, P.; Liu, J.; Zhang, Y.; Chen, J.; Zheng, L.; Hu, T. Mercury speciation and mercury isotope fractionation during ore roasting process and their implication to source identification of downstream sediment in the Wanshan mercury mining area, SW China. Chem. Geol. 2013, 336, 72-79.

(64) Foucher, D.; Ogrinc, N.; Hintelmann, H. Tracing Mercury Contamination from the Idrija Mining Region (Slovenia) to the Gulf of Trieste Using $\mathrm{Hg}$ Isotope Ratio Measurements. Environ. Sci. Technol. 2009, 43, 33-39.

(65) Gehrke, G. E.; Blum, J. D.; Marvin-DiPasquale, M. Sources of mercury to San Francisco Bay surface sediment as revealed by mercury stable isotopes. Geochim. Cosmochim. Acta 2011, 75, 691705 .

(66) Donovan, P. M.; Blum, J. D.; Singer, M. B.; Marvin-DiPasquale, M.; Tsui, M. T. K. Isotopic Composition of Inorganic Mercury and Methylmercury Downstream of a Historical Gold Mining Region. Environ. Sci. Technol. 2016, 50, 1691-1702.

(67) Donovan, P. M.; Blum, J. D.; Singer, M. B.; Marvin-DiPasquale, M.; Tsui, M. T. K. Methylmercury degradation and exposure pathways in streams and wetlands impacted by historical mining. Sci. Total Environ. 2016, 568, 1192-1203.

(68) Olsvik, P. A.; Brattås, M.; Lie, K. K.; Goksøyr, A. Transcriptional responses in juvenile Atlantic cod (Gadus morhua) after exposure to mercury-contaminated sediments obtained near the wreck of the German WW2 submarine U-864, and from Bergen Harbor, Western Norway. Chemosphere 2011, 83, 552-563.

(69) Solhjell, E.; Lunne, T. U-864 2013 Soil Survey; NGI: Oslo, 2013, p 199.

(70) Hu, H.; Lin, H.; Zheng, W.; Tomanicek, S. J.; Johs, A.; Feng, X.; Elias, D. A.; Liang, L.; Gu, B. Oxidation and methylation of 
dissolved elemental mercury by anaerobic bacteria. Nat. Geosci. 2013, 6, 751-754.

(71) Colombo, M. J.; Ha, J.; Reinfelder, J. R.; Barkay, T.; Yee, N. Anaerobic oxidation of $\mathrm{Hg}(0)$ and methylmercury formation by Desulfovibrio desulfuricans ND132. Geochim. Cosmochim. Acta 2013, 112, 166-177.

(72) Havelková, M.; Dušek, L.; Némethová, D.; Poleszczuk, G.; Svobodová, Z. Comparision of Mercury Distribution Between Liver and Muscle - A Biomonitoring of Fish from Lightly and Heavily Contaminated Localities. Sensors 2008, 8, 4095-4109.

(73) Kwon, S. Y.; Blum, J. D.; Chirby, M. A.; Chesney, E. J. Application of mercury isotopes for tracing trophic transfer and internal distribution of mercury in marine fish feeding experiments. Environ. Toxicol. Chem. 2013, 32, 2322-2330.

(74) Xu, X.; Wang, W.-X. Isotopic fractionation during the uptake and elimination of inorganic mercury by a marine fish. Environ. Pollut. 2015, 206, 202-208. 